\title{
TANGGUNG JAWAB KOMISI PEMILIHAN UMUM ATAS HAK MEMILIH YANG TIDAK TERDAFTAR DALAM DAFTAR PEMILIHAN TETAP (STUDI KASUS DI DESA CIMEKAR KECAMATAN CILEUNYI KABUPATEN BANDUNG)
}

\author{
Dany Yulianingsih \\ (Mahasiswa Program S1 Fakultas Hukum Universitas Tarumanagara) \\ (Email: Danyyulianingsih@yahoo.co.id)
}

\section{Dr. H. Rasji, S.H., M.H.}

(Corresponding Author)

(Dosen Tetap Universitas Tarumanagara, Meraih Sarjana Ilmu Hukum dari Fakultas Hukum Universitas Tarumanagara, Magister Ilmu Hukum dari Fakultas Hukum Universitas Indonesia)

(Email: rasji@fh.untar.ac.id)

\begin{abstract}
The general election regulated in constitution No 7 on 2017 in a manner implemented one, freely, secretly, and fair is one important element because in the general election apart from the mechanism for selecting leaders to guarate periodic chanfe in leadership. This is a manifestation of the from of political night of citizens. Because Indonesia is one of the countries which uphotls human rights (HAM). In a state responsibilities for implementation and who registered the data vote in pemilukada, updating vote data based on population data prepared and submitted by the govermment for unregistered vote as potensial vote in the election can make a claim by the personality in a governing election in carry out on duty calling in conducting outreach and direction to the society, menkers of the public who are not registered on the permarent votes list still can using it political right in the from of the right to votr. that's enogh to bring the identification card (KTP), passport or other identity that prones it is a local society or a move from another area. Letter as or transder letter for resettled residents from another regions. How ever this was not finish by election officials at the district level, so that the community still did'nt exercise their voting rights in the elections of 2015.
\end{abstract}

Keywords: the general election, responbility, a voting list fixed

\section{PENDAHULUAN}

\section{A. Latar Belakang}

Tanggung jawab adalah suatu keharusan bagi seseorang atau negara untuk melaksanakan dengan selayaknya apa yang telah diwajibkan kepada masyarakat. ${ }^{1}$ terdapat dua macam istilah tanggung jawab atau pertanggung jawaban kpu yang merupakan terjemahan dari responsibility dan liability dan sering digunakan secara rancu atau diperlakukan untuk menunjuk pada

\footnotetext{
${ }^{1}$ Andi hamzah, Perlindungan Hak-Hak Asasi Manusia, (Bandung: Binacipta,1986)
} 
maksud yang sama.Untuk itu setiap warga masyarakat mempunyai persamaan hak di hadapan hukum dan pemerintahan. ${ }^{2}$

Warga masyarakat diartikan pula sebagai rakyat yang menetap di suatu wilayah dan rakyat tertentu dalam hubunganya dengan masyarakat.Dalam hubungan antar warga negara dan masyarakat, warga negara mempunyai kewajiban terhadap masyarakat dan sebaliknya negara juga mempunyai hakhak yang harus diberikan dan dilindungi oleh masyarakat. ${ }^{3}$ Salah satu kepemilikan yang melekat dalam diri identitas seorang warga adalah hak dan kewajibanya secara resiprokalitas. ${ }^{4}$ Peran atau peranan dari warga masyarakat itu tercermin secara ekplisit pada sejumlah hak dan kewajibanya sebagai warga masyarakat.Sebaliknya warga masyarakat memiliki sejumlah hak dan kewajiban pada masyarakat. ${ }^{5}$

Pasal 28D ayat (3) Undang-Undang Dasar 1945 adalah warga negara berhak memperoleh kesempatan yang sama dalam pemerintahan. UndangUndang Dasar 1945 menegaskan pula bahwa kewajiban warga masyarakat bersamaan kedudukanya di dalam hukum dan pemerintahan dan wajib menjunjung hukum dan pemerintahan itu dengan tidak ada kecuali serta wajib ikut serta dalam pembelaan masyarakat. Salah satu dari hak warga masyarakat yang dijamin UUD 1945 adalah hak untuk turut serta dalam pemerintahan, yang kewajiban pemerintah sebagai pelayan warga masyarakat.

Salah satunya memberikan pelayanaan kepada masyarakat untuk ikut serta dalam pemilu yaitu dengan menjalankan tugas dan wewenangnya yakni salah satunya memberikan dan menetapkan syarat-syarat administrasi yang harus dipenuhi oleh warga masyarakat untuk dapat melaksanakan hak politiknya berupa hak memilih.

2 A. Muchtar Ghazali dan Abdul Majid, Pendidikan Kewarganegaraan (Materi Kuliah di Perguruan Tinggi islam), (Bandung : Pt Remaja Rosdakarya, 2016), hlm. 61

${ }^{3}$ H Kaenal, M.S dan Zulbaid, Pendidikan Kewarganegaraan, (Yogyakarta : Paradigma, 2010), hlm. 117

${ }^{4}$ Resiprokalitas Artinya ia memiliki hubungan timbal balik yaitu hak dan kewajiban diantara kedua belah pihak. Seorang warga memiliki hak dan kewajiban terhadap pemerintahan, demikian pula sebaliknya pemerintahan memiliki hak dan kewajiban terhadap warga negara

${ }^{5}$ Winarno, M.Si, Kewarganegaraan Indonesia, (Bandung : Alfabeta, 2009), hlm. 18 
Pemilihan umum diatur di dalam Undang-Undang Nomor 7 Tahun 2017 Tentang Penyelenggara Pemilu ( UU No.7 Th 2017) yang dilaksanakan secara terbuka, bebas, rahasia dan adil merupakan salah satu unsur penting karena dalam pemilihan umum selain dari mekanisme untuk menyeleksi pemimpin untuk jaminan perubahan secara periodik kepemimpinan, bentuk warga masyarakat. Sebab salah satu negara yang menjunjung tinggi hak asasi manusia (HAM) dalam bernegara.

Pemilihan Umum merupakan bentuk dari perwujudan hak politik warga negara dan juga merupakan bentuk kewajiban yang diberikan oleh pemerintah terhadap warga negaranya. Salah satunya adalah pemilihan kepala daerah, yang telah berlangsung pada tanggal 9 Desember 2015, yang dilaksanakan secara serentak di seluruh daerah di Indonesia.

Pemilukada dapat dipastikan bahwa prinsip dan asas-asas pemilu dapat dilaksanakan secara baik dan benar. Namun hampir di setiap tahap penyelenggara pemilu terjadinya suatu permasalahan atau pelanggaraan baik oleh penyelenggaran, peserta pemilukada, ataupun oleh pemilih. Seperti terjadi pada proses penyelenggara pemilukada serentak tahun 2015 yang diselenggarakan pada tanggal 9 Desember 2015. Pada pemilukada tersebut di Desa Cimekar Kecamatan Cileunyi Kabupaten Bandung terjadi masalah berupa 185 warga masyarakat sebagai penduduk desa yang tidak terdaftar dalam daftar pemilihan tetap (DPT) di Komisi Pemilihan Umum (KPU), sehingga 185 warga desa tersebut hilang hak politiknya berupa hak memilih kepala daerah. Keadaan ini dapat merugikan hak warga dalam menggunakan hak memilihnya. ${ }^{6}$ Warga masyarakat yang memenuhi untuk memiliki syarat administrasi tetapi tidak terdaftar pemilukada di Komisi Pemilihan Umum (KPU), Komisi Pemilihan Umum (KPU) sudah ditetapkan bahwa 185 warga masyarakat sebagai penduduk desa tidak tercantumkan daftar pemilihan tetap (DPT) di Komisi Pemilihan Umum (KPU).

Berdasarkan uraian latar belakang di atas, penulis tertarik untuk melakukan kajian lebih lanjut permasalahan hukum tersebut dan

\footnotetext{
${ }^{6}$ Hasil Wawancara dengan ketua RT di Desa Cimekar .
} 
menuangkannya dalam bentuk skripsi dengan judul "TANGGUNG JAWAB KOMISI PEMILIHAN UMUM ATAS HAK MEMILIH YANG TIDAK TERDAFTAR DALAM DAFTAR PEMILIHAN TETAP (STUDI KASUS DI DESA CIMEKAR KECAMATAN CILEUNYI KABUPATEN BANDUNG).

\section{B. Permasalahan}

Berdasarkan latar belakang yang telah diuraikan oleh penulis, maka permasalahan yang ingin dikaji lebih lanjut adalah :

1. Bagaimana upaya hukum yang dapat di lakukan oleh warga Desa Cimekar Kecamatan Cileunyi Kabupaten Bandung untuk mendapatkan hak memilihnya?

2. Bagaimana tanggung jawab Komisi Pemilihan Umum terhadap hak memilih warga desa Cimekar yang tidak terdaftar di dalam daftar pemilihan tetap?

\section{Metode Penelitian}

Metode yang digunakan metode penelitian hukum normatif untuk itu diperlukan penelitian yang merupakan suatu rencana pokok dalam pengembangan ilmu pengetahuan.pendekatan normatif yaitu merujuk pada substansi judul, maka penelitian ini menggunakan studi kasus yang digali adalah entitas tunggal atau fenomena (kasus) dari suatu dan aktivitas (berupa program, kejadian, proses intuisi atau kelompok sosial) serta mengumpulkan detail informasi dengan menggunakan berbagai prosedur penggumpulan data selama kasus itu terjadi.

\section{Jenis Penelitian}

Dalam penelitian ini digunakan metode penelitian hukum normatif untuk itu diperlukan penelitian yang merupakan suatu rencana pokok dalam pengembangan ilmu pengetahuan.Menurut Soerjono Soekanto pendekatan normatif yaitu merujuk pada substansi judul, maka penelitian ini menggunakan studi kasus yang digali adalah entitas tunggal atau fenomena (kasus) dari suatu dan aktivitas (berupa program, kejadian, proses intuisi atau kelompok sosial) serta mengumpulkan detail informasi dengan menggunakan 
berbagai prosedur penggumpulan data selama kasus itu terjadi. ${ }^{7}$ Penulis dalam penelitian ini menggunakan metode studi kasus karena mengumpulkan detail informasi dengan menggunakan prosedur pengumpulan data untuk mendeskripsikan tentang Tanggung Jawab KPU atas hak memilih yang terdaftar dalam daftar pemilihan tetap di desa Cimekar kec. Cileunyi kab. Bandung sebagai suatu analisis kasus yang terjadi.

\section{Sifat Penelitian}

Sifat penelitian yang digunakan dalam penelitian ini bersifat deskriptif, yaitu mengambarkan gejala-gejala di lingkungan masyarakat terhadap kasus yang di teliti. ${ }^{8}$ Penelitian ini diharapkan dapat memberikan informasi secara lengkap dan jelas mengenai Tanggung Jawab KPU atas hak memilih yang terdaftar dalam daftar pemilihan tetap di Desa Cimekar Kec. Cileunyi Kab. Bandung

\section{Analisis Penelitian}

Analisis kualitatif diartikan sebagai kegiatan menganalisis data secara kompreship, yaitu data sekunder dari berbagai kepustakaan dan literatur baik yang berupa buku, peraturan perundangan dan hasil penelitian lainnya maupun informasi dari media massa. ${ }^{9}$

\section{Jenis Data}

Jenis data yang digunakan peneliti dalam penelitian ini adalah jenis data sekunder, dan data primer wawancara dengan masyarakat dan KPU. Sumber data sekunder yang digunakan oleh peneliti dalam penelitian ini yaitu adalah bahan pustaka, berupa buku, artikel, peraturan perundang-undangan dan

${ }^{7}$ Soerjono Soekanto dan Sri Mamudji , Penelitian Hukum Normatif SuatuTinjaun Singkat (Jakarta : PT. RajaGrafindo Persada,2003), hlm. 13-14

${ }^{8}$ Soerjono Soekanto, Metode Penelitian Hukum (Jakarta : Universitas Indonesia Press, 1986), hlm

${ }^{9}$ Soerjono Soekanto, Pengantar Penelitian Hukum, (Jakarta : UI-PRESS, 1986), hlm. 52 
sumber data kepustakaan lainnya. Jenis bahan hukum yang digunakan dalam penelitian ini adalah bahan hukum primer, sekunder dan tertier.

a. Bahan hukum primer adalah bahan-bahan yang isinya mempunyai kekuatan mengikat kepada masyarakat. Terkait dengan permasalahan yang dibahas bahan hukum primer yang penulis pakai adalah UndangUndang No 10 tahun 2016 Tentang Penyelenggaran Pemilihan Gubernur Bupati dan Walikota, UU No 7 tahun 2017 Tentang Penyelenggaran Pemilu, PKPU No 2 Tahun 2017 Tentang pemutakhiran data dan daftar pemilih dalam pilkada.

b. Bahan hukum sekunder adalah bahan hukum yang isinya memberikan informasi mengenai bahan hukum primer. Dalam hal ini bahan hukum sekunder yang dimaksud adalah jurnal-jurnal, makalah-makalah maupun buku-buku mengenai hak politik, dan juga memuat ketentuan-ketentuan maupun teori-teori dan pandangan-pandangan terkait hak politik kaitanya dengan syarat Tanggung Jawab KPU atas hak memilih yang tidak terdaftar dalam daftar pemilihan tetap.

c.Bahan Hukum Tertier, yakni bahan yang memberikan petunjuk maupun penjelasan terhadap bahan hukum primer dan sekunder, dalam hal ini bahan hukum tertier, yang digunakan penulis adalah kamus-kamus hukum.

\section{Spesifikasi Penelitian}

Spesifikasi penelitianyang digunakan adalah mengkaji norma-norma hukum positif dalam peraturan perundang-undangan (ius constitutum) dan memberikan gambaran yang bersifat analisis deskriptif. Penelitian ini akan membahas spesifik mengenai uraian tentang Tanggung Jawab KPU atas hak memilih yang tidak terdaftar dalam daftar pemilihan tetap di desa Cimekar kec. Cileunyi kab. Bandung sebagai suatu analisis kasus yang terjadi.

\section{Teknik Analisis Data}


Teknik analisis data yang penulis gunakan dalam penelitian ini adalah teknik atau metode analisis kualitatif. Metode kualitatif adalah suatu tata cara penelitian yang menghasilkan data deskriptif analitis, yaitu apa yang dinyatakan oleh informan secara lisan melalu wawancara, dan juga perilakunya yang nyata, yang diteliti dan dipelajari sebagai sesuatu yang utuh.

\section{PEMBAHASAN}

\section{A. Upaya Hukum Yang Dapat Di Lakukan Oleh Warga Desa Cimekar} Kecamatan Cileunyi Kabupaten Bandung Untuk Mendapatkan Hak Memilihnya Hak memilih disebut dengan hak politik dimana warga

Masyarakat didesa Cimekar Kecamatan Cileunyi sesuai undangundang berhak mendapatkan kesempatan yang sama dalam hukum dan pemerintahan, salah satunya dengan cara hak politik yang didapatkan oleh warga masyarakat serta dijamin oleh undang-undang yakni hak untuk dipilih dan memilih. Untuk mendapatkan hak memilihnya warga masyarakat dapat dilakukan secara administrasiyang diperlukan hak memilih sendiri, dimana hak memilih secara adminisitrasi bagi warga masyarakat agar dapat memenuhi hak memilih, bukan hanya dilindungi oleh warga masyarakat sebagai calon pemilih akan tetapi Komisi Pemilihan Umum yang bertanggung jawab atas terlaksananya proses penyelenggaraan pemilu bertanggung jawab untuk turut serta menjaga dan dilindungi hak politik berupa hak memilih secara administrasi sebab merupakan kewajiban yang dibebankan kepada negara lewat badan yang bertugas dalam pemilu untuk dapat memberikan salah satunya yakni dengan menyeimbangkan serta menjalankan terhadap kewajiban warga negara sebagai calon pemilih.

Adapun upaya yang dapat dilakukan oleh185 masyarakat Desa Cimekar Kecamatan Cileunyi untuk dapat memenuhi hak memilih dilakukan oleh :

\section{Mengajukan permohonan KPU}


Masyarakat yangdatang ke Komisi Pemilihan Umum (KPU) untuk mengajukan permohonan, sehingga masyarakat mendaftarkan diri untuk mengisi data formulir sebagai memenuhi hak memilih dalam suatu pemilihan, pemilih yang mempunyai hak memilih tapi tidak terdaftar untuk memilih pemilihan umum pilkada di Desa Cimekar agar kita bisa untuk memilih, para pemilih di minta untuk melakukan pengecekan apakah namanya sudah terdaftar di Daftar Pemilihan Tetap (DPT) atau belum. Komisi Pemilihan Umum (KPU) berharap Warga Negara Indonesia (WNI) yang sudah punya hak pilih proaktif untuk melakukan pengecekan. ${ }^{10}$

Komisi Pemilihan Umum (KPU) menjelaskan kepada masyarakat cara mengecek nama Daftar Pemilihan Tetap (DPT) caranya bisa dilakukan dengan cara datang langsung ke kantor desa/kelurahan domisili. Petugas akan membantu pemilih untuk mengecek apakah yang bersangkutan sudah terdaftar dalam DPT atau belum.

Masyarakat melakukan / melengkapi identitas untuk mendapatkan hak suaranya dalam pemilihan pilkada :

1) Isi formulir

2) KTP atau e-KTP

3) Jika belum memiliki e-KTP bisa melampirkan dokumen pendukung lainnya seperti surat keterangan Kartu Keluarga, Paspor, atau Surat Izin mengemudi (SIM).

Meskipun pemilih yang belum mendapatkan formulir C6 atau pemberitahuan pemilih dapat meminta kepada panitia TPS.Namun KPU mengatakan C6 bukan sebagai syarat memilih pada Pemilukada Tahun 2015.Sehingga pemilih yang terdaftar dalam DPT tetap dapat mencoblos meski tidak mendapatkan C6.

10 Wawancara dengan bapak Agus Hasbi selaku Anggota Divisi Hukum dan Pengawasan KPU Kabupaten Bandung Tanggal 12 November 2019 
Komisi Pemilihan Umum (KPU) menerima baik masyarakat untuk melaporkan tentang hak suara pemilihan yang belum terdaftar, KPU menjelaskan pendapatnya dengan 2 hal yaitu:

1) Sebagai warga negara yang baik, salah satu bukti warga negara yang baik ikut bertanggung jawab (wajib) dan berhak untuk andil dalam menetapkan kesejahteraan hidup.

2) Pemilihan Umum merupakan sarana kedaulatan rakyat, pemilihan umum merupakan cara terbaik dan martabat bagi rakyat untuk secara berpratisipasi dan memilih pilkada.

3) Bertanggung jawab memilih Bupati di Desa Cimekar.

4) Jika tidak menggunakan hak pilih (golput) kesempatan memilih pemimpin justru akan digunakan oleh orang lain. Akan sangat berbahaya kalau yang menggunakan hak itu justru orang/pihak yang tidak bertanggung jawab terhadap kelangsungan Pancasila, Bhineka Tunggal Ika, kesejahteraan hidup bermasyarakat dan yang menjaga prinsip inklusif toleran.

Upaya Hukum yang telah di jelaskan diatas Komisi Pemilihan Umum hak politik warga masyarakat secara administratif dengan menjalankan tugas dan wewenangnya dalam penyelenggaraan pemilu yakni melakukan tugas-tugasnya secara administrasif yaitu menjalankan tugas pendaftaran pemilih telah calon memilih maka Komisi tersebut ikut serta dalam hak politik warga masyarakat sehingga dapat menggunakan hak pilihnya dalam suatu pemilihan umum.

Pemerintah dalam menjalankan tugasnya sebagai pelaksana negara yang bertugas melaksanakan negara dalam pendaftaran calon pemilih dalam pilkada (pemilu) tentu harus mengacu kepada asas-asas pemerintahan yang baik (Good Goverment) melakukan pelaksanaan aturan tersebut berjalan dengan baik, yakni :

a) Azas Keadilan

Menghendaki agar dalam melakukan tindakan, pemerintah tidak berlaku sewenang-wenang. 
b) Asas Persamaan

Hal-hal yang sama harus diperlakukan sama artinya pejabat negara harus memberikan perlakuan yang sama terhadap warga masyarakat dalam melaksanakan setiap tugasnya.

c) Azas kepastian Hukum (Principle Of Legal Security)

Azas yang menghendaki dihormatinya hak yang telah diperoleh seseorang berdasarkan suatu keputusan, badan atau pejabat administrasi negara.

d) Azas kebijaksanaan

Mengehnedaki agar dapat melaksanakan tugasnya, pemerintahan diberi kebebasan untuk melakaukan kebijaksanaan untuk kepentingan umum, tanpa harus menunggu instruksi.

Komisi Pemilihan Umum dalam upaya hukum untuk mendapatkan hak memilih masyarakat secara administratif yakni dengan cara teliti dan dengan sungguh dalam melakukan tugasnya sebagai KPU yang bertanggung jawab dalam proses penyelenggaraan pemilu yaitu melaksanakan tahapan perkerjaannya dari awal sampai akhir sehingga masyarakat terdaftar sebagai calon pemilih. Yaitu sesuai dengan UndangUndang Nomor 30 Tahun 2014 tentang Administrasi Pemerintahan disebutkan bahwa: "pejabat pemerintahan harus menjalankan tugas dan wewenangnya dengan baik untuk meningkatakan kualitas penyelenggaraan pemerintahan”.

Meningkatkan penyelenggaraan pemerintahan pejabat atau badan pemerintahan harus mengacu pada asa-asas umum pemerintahan yang baik dan berdasarkan ketentuan perundang undangan. Adapun dibentuknya undang-undang tentang administrasi negara untuk mencegah kesewenang-wenangan atas hak dan kewajiban pejabat atau badan penyelenggara dalam menjalankan setiap tugas dan wewenangnya. Yaitu sesuai dengan tujuan undang-undang ini adalah : 
1) Menciptakan tertib penyelenggaraan administrasi pemerintahan.

2) Menciptakan kepastian hukum.

3) Mencegah terjadinya penyalahgunaan wewenang.

4) Menjamin akuntabilitas badan/pejabat pemerintahan.

5) Melaksanakan ketentuan peraturan perundang-undangan.

6) Memberikan pelayanan yang sebaik-baiknya kepada masyarakat. ${ }^{11}$

Adapun rangkain kegiatan yang dilakukan oleh Komisi Pemilihan Umum (KPU) pemilu sehingga warga masyarakat dapat terdaftar sebagai calon pemilih dan dimulai dari kegiatan Penyusunan Daftar Pemilih, dilakukan berdasarkan data Kependudukan dan Data Penduduk Potensial Pemilih Pemilu (DP4). ${ }^{12}$ yangdisiapkan oleh Pemerintah yakni Departemen Dalam Negeri beserta Pemerintah Daerah. Data kependudukan dan DP4, harus sudah tersedia dan diserahkan kepada KPU Kab/Kota paling lambat 6 (enam) bulan sebelum hari dan tanggal pemungutan suara. DP4 memuat Nomor Induk Kependudukan (NIK), nama lengkap, tempat/tanggal lahir, status, jenis kelamin, alamat/tempat tinggal dan cacat yang disandang.

KPU Kabupaten/Kota dengan dibantu oleh PPS melakukan pemutakhiran data dengan menggunakan sebagai bahan, DP4 yang diterima oleh pemerintah yang ada dalam wilayah kerjanya. Hasil ini, lebih lanjut yang terdiri dari $\mathrm{Rt}$, $\mathrm{Rw}$ atau nama lain dan warga masyarakat sendiri yaitu PPDP di tingkat desa yang bertugas memutakhirkan data per/TPS yang diangkat dan diberhentikan oleh PPS. Proses pemutakhiran data pemilih ini dilaksanakan paling lambat 3 bulan.

Hasil pemutakhiran data pemilih tersebut, PPS menyusun DPS dengan berbasis Rukun Tetangga. Penyusunan DPS ini dilakukan. $\mathrm{Bab}$ II

${ }^{11}$ Dalam Undang-Undang Nomor 30 Tahun 2014 Pasal 3 tentang Adminitrasi Pemerintahan

${ }^{12}$ Daftar Penduduk Potensial Pemilih Pemilihan (DP4) adalah data yang disediakan pemerintah yang berisikan data penduduk yang memenuhi persyaratan sebagai pemilih pada saat pemilihan diselenggarakan. 
Setelah disusun PPS mengumumkan, mendapat masukan dan tanggapan dari masyarakat diterima oleh PPS 14 (empat belas) hari kerja sejak diumumkan setelah menerima masukan dan tanggapan dari masyarakat, PPS wajib memperbaiki DPS berdasarkan masukan dan tanggapan dari masyarakat. Kemudian PPS mengumumkan kembali DPS yang sudah diperbaiki untuk mendapatkan lagi masukan dan tanggapan dari masyarakat selama 3 (tiga) hari kerja. Setelah menerima masukan dan tanggapan lagi dari masyarakat, PPS kembali memperbaiki DPS. Selanjutnya DPS yang sudah diperbaiki oleh PPS untuk kedua kalinya dikirimkan kepada KPU kabupaten/kota yang bersangkutan melalui PPK untuk dijadikan bahan penyusunan DPT oleh KPU Kabupaten/Kota.

\section{Warga Masyarakat Mendatangi Tempat Pemungutan Suara (TPS)}

Masyarakat yang datang langsung ke Tempat Pemungutan Suara (TPS),sebaiknya sebelum berangkat patut memeriksa dahulu apakah identitas sudah ada dalam data Daftar Pemilihan Tetap (DPT), pemilih bisa datang dan melihat papan DPT yang di pajang di tiap-tiap TPS domisili pemilih. Masyarakat dapat mencari namanya masing-masing di papan tersebut secara manual.

Daftar Pemilihan Tetap (DPT) diumumkan pada papan pengumuman ada diluar TPS,sehingga ketika bila tidak membawa atau membaca formulir, masuk saja ke TPS lapor ke kelompok petugas Pemungutan Suara (KPPS) lalu isi daftar hadir dan sampaikan bahwa bapak/ibu sudah ada di dalam TPS.

Komisi Pemilihan Umum mengecek identitas warga yang akan memberikan hak suara yang terdaftar seperti KTP jika semua sudah terisi lengkap warga masyarakat berhak untuk memilih.

Komisi Pemilihan Umum (KPU) harus dapat memastikan da KPU harus memastikan bahwa setiap warga masyarakat yang memiliki hak pilih harus di jamin keikutsertaanya di pemilu. Penyelenggaran 
pemilu jangan sampai terkesan mengabaikan seperti masyarakat yang ingin menggunakan hak pilihnya.

Masyarakat melaksanakan setiap tahapan pelaksanaan pemilu sesuai arahan dan sosialisasi badan penyelenggara pemilu yakni :

1) Warga masyarakat mendapatkan hak politik secara adminitratif dapat dilakukan dengan menjaga syarat administrasi yang dibutuhkan sehingga warga masyarakat memenuhi syarat memilih serta mematuhi dan mengikuti tahapan yang dilakukan oleh badan penyelenggara dalam proses pendaftaran calon pemilih.

2) Tugas badan penyelenggara pemilu di tingkat desa (PPS) menyampaikan hasil pemutakhiran data Daftar Pemilih Sementara (DPS) kepada masyarakat, masyarakat sendiri harus mampu mengikuti (aktif) dalam setiap tahapanya dengan aktif memberikan masukan dan tanggapan kepada PPS atau badan penyelenggara pemilu dengan sebutan lain pada saat pengumuman DPS sehingga ada perbaikan daftar calon pemilih dan seterusnya ketika pengumuman daftar pemilih tetap setelah adanya perbaikan dari DPS aktif memeberikan tanggapan. Tanggapan dari masyarakatan ini dimaksudkan untuk perbaikan jika dalam data yang telah dimuat terdapat kesalahan penulisan nama, alamat atau bahkan nama mereka tidak tercantum di dalam daftar pemilih.

3) untuk menjaga hak politiknya berupa hak memilih warga masyarakat dapat pula mengecek data daftar pemilih di situs online yang telah disediakan oleh badan penyelenggara pemilu. Dengan aktif melakukan pengecekan terhadap situs daftar pemilih, warga masyarakat akan mengetahui sejauhmana tugas yang dilakukan oleh badan penyelenggara pemilu, apakah sudah terdaftar atau bahkan tidak dalam DPT tersebut, sehingga apabila ada kesalahan para petugas dalam mendata setiap warga masyarakat baik itu dalam penulisan nama, alamat dan sebagainya atau bahkan belum 
terdaftar, masyarakat dapat langsung segera melapor kepada Tempat pemungutan Suara (TPS) setempat.

Langkah-langkah tersebut merupakan suatu bentuk upaya hukum hak memilih warga masyarakat secara administratif dalam pelaksanaan pilkada sehingga warga masyarakat dapat memenuhi hak memilih dan secara bebas dapat menggunakan hak memilihnya seperti warga masyarakat yang lainya.

Hak memilih warga masyarakat secara adminitratif dilakukan warga masyarakat itu sendiri dan tentunya sama-sama dilakukan oleh badan penyelenggara pemilu yang bertugas mendaftarkan warga negara yang telah memenuhi syarat memilih untuk dapat memperoleh hak politiknya secara administratif berupa hak memilih. Sebab warga masyarakat yang telah memenuhi syarat memilih sebagai calon pemilih berhubungan erat dengan tugas badan penyelenggara pemilu, untuk itu baik warga negara atau masyarakat beserta badan penyelenggara pemilu dalam hal ini KPU beserta jajaranya harus mampu mejaga dan menghormati setiap hak dan kewajiban antara keduanya. Untuk itu diharapkan keterbukaan diantara keduanya baik itu badan penyelenggara pemilu (dari mulai KPU sampai jajaran terkecil di tingkat desa yaitu PPDP) untuk saling menjaga dan menghormati setiap tugasnya masingmasing sehingga terwujud penyelenggaraan pemilu yang diharapakan. Seperti yang diamanatkan dalam Undang-Undang Nomor 39 Tahun 1999 tentang Hak Asasi Manusia dalam Pasal 69 :

(1) Setiap orang wajib menghormati setiap hak asasi manusia lain, moral etika dan tata tertib kehidupan bermasyarakat berbangsa dan bernegara.

(2) Setiap hak asasi manusia seseorang menimbulkan kewajiban dasar dan tanggung jawab untuk menghormati hak asasi orang lain secara timbal balik serta menjadi tugas pemerintah untuk menghormati, melindungi, menegakan dan memajukanya. 
Dengan cara saling menghormati hak dan kewajiban diantara keduanya tentulah dapat terpelihara hak politik secara administratif bagi warga negara sehingga masyarakat mampu memenuhi hak memilih dalam suatu pemilihan. Disisi lain badan penyelenggara memberikan hak kepada warga negara dengan melaksanakan setiap tahapan tugasnya dan begitupun dengan warga negara agar menghormati setiap pelaksanaan tugas badan penyelenggara pemilu yaitu dengan mengikuti setiap proses tahapan penyelenggaraan pemilu (pilkada).

\section{B. Tanggung jawab Komisi Pemilihan Umum terhadap hak memilih warga desa Cimekar yang tidak terdaftar di dalam daftar pemilihan tetap}

Setiap warga masyarakat yang telah memenuhi syarat sebagai calon pemilih dan telah terdaftar dalam pemilihan yaitu berhak untuk melaksanakan hak politiknya berupa hak memilih dalam pemilihan umum. Namun bagi masyarakat yang telah memenuhi syarat sebagai calon pemilih tetapi tidak terdaftar dalam Daftar Pemilih Tetap (DPT) seperti kasus 185 warga masyarakat Rt 05 Rw 10 di Desa Cimekar Kecamatan Cileunyi Kabupaten Bandung dalam pemilihan kepala daerah secara serentak yaitu pemilihan Bupati Kabupaten Bandung, masyrakat tersebut sebenarnya masih bisa melaksanakan hak politiknya berupa hak memilih tersebut dengan cara-cara yang telah di sebutkan dalam undang-undang. Adapun secara jelas dalam Undang-Undang dijelaskan bagi warga masyarakat yang tidak terdaftar dalam DPT, mereka masih bisa melaksankaan hak pilihnya dengan solusi sebagai berikut; Bagi masyarakat yang tidak tercantum dalam DPT sehingga warga masyarakat tidak memiliki Surat Undangan C6 sebagai syarat utama dalam melaksanakan hak memilih dalam pemilu, masyarakat tersebut masih dapat melaksanakan hak memilih pada hari $\mathrm{H}$ (Hari Pemilihan) dengan membawa :

1) Kartu Tanda Penduduk (KTP)

2) Kartu Keluarga (KK) 
3) Paspor dan atau Identitas lain yang dapat membuktikan bahwa ia masyarakat setempat

4) Surat A5 atau Surat Pindahan bagi masyarakat pindahan dari daerah lain.

Dengan membawa identitas inilah masyarakat yang tidak terdaftar dalam DPT dapat melaksanakan hak memilih sebagaimana masyarakat lainya, yang nantinya tergabung kedalam Daftar Pemilih Tetap Tambahan (DPT-b2). Yaitu sesuai dengan Pasal 57 Undang-Undang No 7 Tahun 2017 yakni :

(1) Untuk mendapatkan hak memilih warga negara Indonesia harus terdaftar sebagai pemilih;

(2) Dalam hal Warga Negara Indonesia tidak terdaftar sebagai pemilih sebagaimana dimaksud pada ayat (1) pada saat pemungutan suara menunjukan Kartu Tanda Penduduk Elektronik (KTP), Kartu Keluarga, Paspor dan/atau identitas lain sesuai peraturan perundang-undangan.

Adapun solusi atau cara yang mestinya dilakukan oleh badan penyelenggara pemilu sesuai dengan kasus yang terjadi di desa Cimekar sehingga 185 warga masyarakat tersebut tidak melaksanakan hak memilihnya KPU dan badan penyelenggara lainya mampu memahami kondisi masyarakat setempat, yakni:

Pertama, ketika masyarakat tidak melaksanakan hak memilih yang disebabkan tidak terdaftar dalam DPT, KPU beserta jajaranya terutama PPS sebagai badan penyelenggara yang paling dekat dengan masyarakat mampu mengkondisikan masyarakat setempat dengan cara memberi arahan dan sosialisasi pada hari $\mathrm{H}$ pemilihan kepada masyarakat setempat bahwa bagi masyarakat yang tidak tercantum dalam DPT masih dapat menggunakan hak pilihnya dengan membawa syarat lain dari pada Surat Undangan C6 yaitu KTP, KK, Paspor atau Identitas lain dan Surat Pindahan A5 bagi masyarakat pindahan dari daerah lain sesuai amanat Undnag-Undang yang mengaturnya. 
E-ISSN : 2655-7347

Sehingga dengan demikian tidak ada alasan bagi masyarakat tidak melaksanakan hak memilihnya dalam pemilihan kepala daerah tersebut serta tidak akan terjadi kecemburuan sosial dari pada masyarakat setempat terhadap masyarakat lainya yang menerima surat undangan C6.

Kedua, apabila 185 masyarakat tersebut tidak melaksanakan hak memilih karena faktor geografis yaitu faktor jarak pemukiman masyarakat lebih dekat dengan TPS 24 sedang kouta di TPS 24 penuh, dan masyarakat tersebut harus melakasanakan hak memilih di TPS 10 akan teteapi jarak dari pemukiman sampai kepada TPS 10 sangat jauh, KPU dan Penyelenggara Dengan menambah jumlah TPS, masyarakat dapat melaksanakan hak memilih atau pencoblosan dengan TPS tambahan tersebut disediakan dekat dengan pemukiman masyarakat RT 05, sehingga tidak ada alasan bagi masyarakat tidak menggunakan hak memilih karena faktor jarak.

Ketiga, masyarakat RT 05 tidak melaksanakan hak politik berupa hak memilih dalam pemilihan umum kepala daerah yang diselenggarakan serentak di seluruh wilayah di Indonesia karena rasa jenuh masyarakat terhadap penyelenggaraan pemilu, masyarakat beranggapan bahwa pemilihan umum diselenggarakan untuk memilih pemimpin yang berkualitas sesuai pilihan rakyat itu sendiri akan tetapi setelah pemimpin itu terpilih tidak ada perubahan lebih baik yang dirasakan masyarakat, seolah semua janji yang telah diberikan oleh para calon pemimpin ketika sebelum pemilihan (kampanye) tidak ada buktinya semuanya tetap sama. ini menjadi tugas partai politik dalam memberi pendidikan politik kepada masyarakat akan pentingnya melaksanakan pemilu.

Keempat, faktor utama yang menyebabkan 185 warga masyarakat tidak melaksanakan hak memilih dalam pemilihan umum kepala daerah yakni tidak terdaftarnya penduduk tersebut dalam Daftar Pemilih Tetap (DPT), karena sebab inilah masyarakat tidak menerima surat undangan C6 seperti masyarakat lainya yang akhirnya mendorong berbagai alasan untuk tidak melaksanakan hak memilih seperti, kecemburuan sosial, faktor jarak, rasa jenuh terhadap penyelenggaraan pemilu yang terjadi akibat kelalaian petugas 
penyelenggara pemilu di tingkat desa dalam mendata masyarakat ke dalam daftar pemilih sebagai calon pemilih.. Solusi masyarakat yang dapat dilakukan oleh badan penyelenggara pemilu dalam melaksanakan tugasnya yaitu melakukan Sosialisasi dan arahan terhadap masyarakat bahwa warga masyarakat yang tidak terdaftar dalam DPT masih dapat menggunakan hak politik berupa hak memilihnya yaitu dengan membawa Kartu Tanda Penduduk (KTP), Kartu Keluarga (KK), Paspor dan atau Identitas lain yang dapat membuktikan bahwa masyarakat setempat, Surat A5 atau Surat Pindahan bagi masyarakat pindahan dari daerah lain. Namun hal ini tidak dilakukan oleh petugas pemilu di tingkat Desa sehingga masyarakat tersebut tetap tidak melaksanakan hak memilihnya dalam pilkada 2015.

Adapun beberapa faktor-faktor tanggung jawab Komisi Pemilihan Umum terhadap hak memilih warga desa Cimekar yang tidak terdaftar di dalam Daftar Pemilihan Tetap (DPT) yaitu :

1) Tanggung jawab KPU kepada warga masyarakat Desa Cimekar tidak dapat hak memilihnya.

2) Tanggung jawab KPU untuk memberikan peringatan kepada KPPS yang salah mendata.

3) KPPS yang salah mendata harus mendata ulang warga masyarakat Desa Cimekar harus memasukan sebagai dalam Daftar Pemilihan Tetap (DPT).

4) KPPS yang lalai memberikan peringatan mengacu pada aturan peraturan yang berlaku.

\section{PENUTUP}

\section{A. Kesimpulan}

Berdasarkan uraian Bab IV maka dapat ditarik kesimpulan terkait permasalahan yang di angkat bahwa upaya hukum yang dapat di lakukan oleh warga Desa Cimekar Kecamatan Cileunyi Kabupaten Bandung untuk mendapatkan hak memilihnya yaitu :

1) Permohonan diajukan kepada Komisi Pemilihan Umum(KPU). 
2) Mendatangi Komisi Pemilihan Umum sehingga mengajukan permohonan Komisi Pemilihan Umum (KPU).

3) Komisi Pemilihan Umum (KPU) memberikan informasi kepada warga masyarakat Desa Cimekar untuk melampirkan data pendukung seperti KTP, Kartu Keluarga atau Paspor atau identitas lainya yang membuktikan masyarakat setempat atau dengan Surat Pindahan (A5).

4) Warga masyarakat protes ke KPU untuk mengecek nama tersebut terdapat di dalam Daftar Pemilihan Tetap (DPT) atau tidak terdaftar di Daftar Pemilihan Tetap (DPT).

5) Warga masyarakat Desa yang tidak terdaftar dalam Daftar Pemilihan Tetap (DPT) harus melengkapi proses administrasi untuk syarat-syarat bukti untuk mendapatkan hak suara secara administrasi inilah sehingga warga masyarakat dapat melaksanakan hak memilihnya.

\section{B.Saran}

Berdasarkan kesimpulan penelitian, maka penulis merekomendasikan berupa saran sebagai berikut :

1) Ditujukan kepada Badan penyelenggara Pemilu

Untuk menjamin terlaksananya hak politik warga masyarakat, sehingga setiap warga masyarakat yang telah memenuhi syarat sebagai pemilih dapat menggunakan hak pilihnya seperti warga masyarakat yang lainya yang telah dijamin oleh undang-undang. Diperlukan pengelolaan kembali terhadap sistem menejemen yang dilaksanakan oleh badan penyelenggara dalam melaksanakan tugasnya sehingga tidak terjadi kembali kerugian yang dirasakan oleh warga negara sebagai pemegang kekuasaan tertinggi dari negara demokrasi.

2) Ditujukan kepada Komisi Pemilihan Umum dan Warga Masyarakat

Agar tidak menimbulkan kesalah pahaman diantara keduanya maka diperlukan sikap keterbukaan, saling menghargai dan menghormati dalam menjalankan setiap tugas dan wewenang diantara keduanya serta hak dan kewajiban yang harus dilaksanakan antara keduanya dalam pelaksanaan pemilu. 
Volume 2 Nomor 2, Desember 2019

E-ISSN : 2655-7347

\section{DAFTAR PUSTAKA}

\section{A. Buku}

Andrianus, Toni. Dkk, Mengenal Teori Teori Politik Sampai Korupsi, (Jakarta : Vnuansa, 2006). 
Ardianto, Elvinaro, Metodologi Penelitian Untuk Public Relations, (Bandung : Simbiosa Rekatama Media,2010)

Abu Bakar, Irfan Karlina Helmanita, Ridwan Al-Makasari, Pranawati,Rita Sholehudin A.Aziz, Sukron Kamil, Agama dan Hak Asasi Manusia, (Jakarta : CSRC, 2009)

Ghazali, Mucthar A, Majid Abdul, Pendidikan Kewarganegaraan (Materi Kuliah di Perguruan Tinggi islam), (Bandung : Pt Remaja Rosdakarya, 2016), hlm.61.

Heribertus U, Setyardi Pertanggungjawaban Negara terhadap pencermaran Udara, Yogyakarta,2001)

Hollyson, Rahmat \& Sri Sundari, PILKADA Penuh Euforia, Miskin Makna, (Jakarta : Bestari Buana Murni, 2015)

Hamzah, Andy Perlindungan Hak-Hak Asasi Manusia, (Bandung: Binacipta,1986)

Kalsen, Hans Teori Umum tentang Hukum dan Negara, (Bandung: PT. Raja Grafindo Persada 2006).

Kencana Syafie, Inu hukum pemerintahan daerah,(Jakarta : Rineka Cipta, 2005).

Kaenal, H M.S dan Zulbaid, Pendidikan Kewarganegaraan, (Yogyakarta : Paradigma, 2010)

Muhammad, Abdulkadir Hukum Perusahaan Indonesia, (Citra Aditya Bakti, 2010)

Makhfudz, Hukum Administrasi Negara, (Yogyakarta : Graha Ilmu, 2013).

M.Si, Winarno Kewarganegaraan Indonesia, (Bandung: Alfabeta, 2009).

Noor, Mahpudin Pancasila, (Bandung :Pustaka Setia, 2016).

Qamar, Nurul Hak Asasi Manusia dalam Negara Hukum demokrasi, Jakarta: PT. Remaja Rosdakarya,2013

Soehino, Hak Asasi manusia. (Yogyakarta : BPFE : Yogyakarta, 2013).

Sirajudin, Dasar-Dasar Hukum Tata Negara, ( Malang : Setara Press, 2015). 
E-ISSN : 2655-7347

\section{B. PERATURAN PERUNDANG-UNDANGAN}

Indonesia. Undang-Undang Nomor 39 Tahun 1999 tentang Hak Asasi Manusia Indonesia.

Indonesia .Undang-Undang Nomor 12 Tahun 2005 tentang Ratifikasi Kovenan Hak-hak Sipil dan Politik Indonesia.

Undang- Undang Dasar Negara Republik Indonesia Tahun 1945

Indonesia. Undang- Undang Nomor 4 Tahun 2018 tentang Peraturan Badan Pengawas Pemilu

\section{KAMUS}

Soekanto, Soerjono. Pengantar Penelitian Hukum. (Jakarta: UI-Press, 1986)

\section{ARTIKEL / ARTIKEL INTERNET}

Wahyu, http://macam-macamaskep-wahyu.blogspot.n1/2011/03/pemenuhanhak-asasi-manusia.html Diakses pada tanggal 17 Oktober 2015 Pukul 10.34 WIB.

http//pemilhanumum.blogspot.com diakses pada tanggal 07 April 2017 pada $14.30 \mathrm{WIB}$ 